\title{
PENGEMBANGAN MEDIA BUKU KEGIATAN TEMA SEMESTER SATU UNTUK MENSTIMULASI KEMAMPUAN BAHASA INGGRIS AUD
}

\author{
Maya Rusalman ${ }^{1}$, Deni Febrini ${ }^{2}$, Fatrica Syafri ${ }^{3}$ \\ Prodi PIAUD, IAIN Bengkulu \\ mayarusalman2018@gmail.com, denifebrini@iainbengkulu.ac.id, $\underline{\text { ricasyafri92@gmail.com }}$
}

DOI: $10.46781 /$ al-abyadh.v4i2.294

\begin{abstract}
Abstrak
Tujuan penelitian yang saya lakukan ini adalah untuk menghasilkan sebuah produk pengembangan media buku kegiatan tema pada pembelajaran semester satu yakni dengan tema diriku, lingkunganku, kebutuhanku, binatang dan tanaman yaitu buku kegiatan berbahasa inggris yang didesain dengan inovasi gambar dan warna yang lebih menarik sehingga anak lebih tertarik untuk melihat dan memperlajarinya, buku ini digunakan untuk meningkatkan kemampuan bahasa inggris anak usia dini di RA As Shaffah Kota Bengkulu. Aadapun metode yang digunakan yakni search and development (R\&D). pengembang dengan model pengembangan richey and klien pada level 1. Dengan mengunakan 7 langkah pengembangan antara lain (1) potensi dan masalah, (2) pengumpulan informasi, (3) desain produk, (4) validasi desain, (5) revisi desain produk, (6) revisi produk dan (7) uji coba produk skala kecil. Penelitian ini mengunakan desain penelitian dengan jumlah 14 anak (satu kelas) untuk mengetahui bagaimana peningkatan bahasa inggris anak. Sedangkan teknik analisis data yang digunakan yakni mengunakan analisis data kualitatif. Berdasarkan hasil analisis data maka diperoleh kesmipulan produk baru hasil pengembangan sudah layak digunakan karena berada dalam katagori "sangat baik" hal ini dibuktikan dengan penilain dari validator.
\end{abstract}

Kata kunci: Menstimulasi Kemampuan Bahasa Inggris AUD

\section{MEDIA DEVELOPMENT OF SEMESTER ONE THEME ACTIVITY BOOK TO STIMULATE AUD ENGLISH ABILITY}

\author{
Maya Rusalman ${ }^{1}$, Deni Febrini ${ }^{2}$, Fatrica Syafri ${ }^{3}$ \\ Prodi PIAUD, IAIN Bengkulu
}

mayarusalman2018@gmail.com, denifebrini@iainbengkulu.ac.id, ricasyafri92@gmail.com

\begin{abstract}
The purpose of this research is to produce a media development product for activity books with the theme of myself, my environment, my needs, animals and plants, namely an English language activity book that is designed with innovative images and colors that are more attractive so that children are more interested in learning, this book is used to improve students' abilities. English AUD at RA As Shaffah Bengkulu city. The method used in this research is research and development $(R \& D)$. This developer adopts the Richey and Client Level 1 development model. By using 7 development steps, namely (1) potential and problems, (2) information gathering, (3) product design, (4) design validation, (5) product design revision, (6) product revision and (7) small-scale product trial. This study uses a research design with a total of 14 children (one class) to find out how to improve children's English. While the data analysis technique used is using qualitative data analysis. Based on the results of data analysis, it is concluded that the new product developed is feasible to use because it is in the "very good" category, this is evidenced by the evaluation of the validator.
\end{abstract}

Keywords: Stimulate AUD English Ability

Al Abyadh

ISSN: 2620-7265

E-ISSN: 2775-7080 


\section{Pendahuluan}

Pendidikan anak usia dini (PAUD) adalah suatu upaya pembinaan yag dimaksudkan untuk membekali anak usia enam tahun untuk membantu pertumbuhan dan perkembangan jasmani dan rohaninye, sehingga siap menerima pendidikan yang lebih tinggi. Hal ini dilakukan melalui penyediaan rangsangan pendidikan dan dukungan, sementara itu, pasa $28 \mathrm{UU}$ Sisdiknas 2003 mengatur bahwa pendidikan nonformal (TK, altafl raudathul atau formalitas lainnya) tempat penitipan anak, atau bentuk lainnya yang sederajat atau pendidikan yang berorientasi lingkungan.

Pertama, pepseptif pengalaman dan pembelajaran. PAUD adalah stimulasi bagi masa yang penuh dengan kejadian penting dan unik yang meletakkan dasar bagi seseorang dimasa dewasa. Kedua, pandangan tentang sifat dan evolusi pembelajaran. PAUD merupakan proses perkembangan dan pembelajaran yang berkelanjutan. Dengan kata lain, pembelajaran awal dan pertumbuhan awal merupakan landasan bagi proses pembelajaran dan perkembangan selanjutnya, menurut orienties, anak-anak yang cukup didorong untuk mengembangkan otaknya di usia dini (otak kiri da otak kanan) siap belajar secara utuh.

pendidikan anak usia dini menawarkan anak kesempatan untuk memaksimalkan kepribadian dan potensinya. Sekolah ana usia dini perlu menyediakan berbagai kegiatan yang dapat mempromosikan berbagai bidang perkembangan. Perkembangan ana usia dini meliputi bidang perkembangan, agama dan moral, fisik motorik, kognitif, sosial, seni dan bahasa. Keenam elemen ini sangat penting untuk pertumbuhan dan perkembangan anak usia dini. Bahasa sangat penting.

Bahasa adalah alat komunikasi yang dihasilkan oleh ucapan manusia dalam bentuk sistem tanda suara, kata, atau pemngelompokan kata adalah bahasa.
Setiap Irang punya akal. Bahasa dapat dilihat hanya sebagai sarana untuk menyampaikan sesuatu. Namun bahasa juga merupakan alat untuk berkomunikasi Atai berinteraksi. Sejumlah komponen berkembang didalam sistem bahasa yang sering dan efektif dikembangkan pasa masa bayi awal adalah bicara. Salah satunya adalah kemampuan anak untuk berbicara secara efektif dan lancar.

Kemampuan bahasa anak usia dini sangat penting karena bahasa adalah lingkungan dimana anak-anak dapat berkomunikasi. Anak-anak belajar mengunakan bahasa untuk menj3di kan pengalaman mereka sebagai simbol untuk komunikasi dan refleks. Keterampilan berbahasa yang responsif (membaca dan mendengarkan) dan ekspresif dapat menunjukan kemampuan berbahasa anakanak (mengngkapan bahasa secara verbal dan nonverbal). Melalui ucapan dengan kata-kata yabg bermakna, anak yang tumbuh dan berkembang mengungkapkan kebutuhan, gagasan dan indaranya. Hak ini dijelaskan dalam surah Ar-Rahman yang disebeutkan dalam Al-Qur'an sebagai dalah satu fitrah manusia. Dimana dalam artinya "Allah maha pengasih, yang telah mengajarkan Al-Qur'an, dia mencipgaka. Manusia, Mengajari nya Lancar Berbicara" (Q.S Al-Rahman 1-4)

Akan tetapi bukan bukan hanya perkembangan bahasa indonesia yang harus dikembangkan. Kemampua. awal anak dalam bahasa asing khusunya bahasa inggris juga harus dikembangkan. Ada bangan kemajuan teknologi di zaman sekarang yang mrmanfaatajan bahasa inggris dan persaingan. menjadi semakin ketat. Pembelajaran bahasa inggris untuk anak usia dini dengan demikn harus diperkenalkan. Baas inggris adalah bahasa asing pertama di indonesia, oleh karena itu harus diajarkan sedini mungkin kepada anak-anak.

Sejak PAUD, bahasa inggris digunakan sebagai media komunikasi. 
Karena bahasa inggris adalah bahasa asing pertama di indonesia, proses pembelajaran. harus mengambil langkah-langkah. Semua unsur pengunaan bahasa harus diperkenalkan pada anak sebelum masa golden age berakhir bagi anak usia 0 sampai 6 tahun, gang merupakan. masa keemasan dan krusal perkembangan masa depan mereka dalam kehidupan. Teknik atau media pembelajaran yang tepat diperlukan untuk meningkatkan atau mendorong kemampha. bahasa inggris anak-anak untuk belajar. Oleh karena itu, penting bagi guru untuk memilih media yang sesuai untuk anak usia dini.

Namun, anak-anak seringkali tidak dapat menguasai bahasa lain termasuk bahasa inggris, beberapa peneliti menunjukan bahawa pembelajaran secara umum kurang baik, seperti yang saya lakukan saat merangsang keterampilan bahasa, khusunya bahasa inggris. Berdasarkan temuan pertama yang dilihat di $\mathrm{Ra}$ Asshafah Kota bengkulu. Belum adanya pengetahuan bahasa asing bagi anak usia dini serta kurangnya media untuk meningkatkan kemampuan bahasa asing pada masa bayi awal. Tidak hanya pembelajaran bahasa inggris yang terlalu luas, akan tetapi bahasa inggris hanyalah pembelajaran bahasa yang dangkal dan tidak berulang-ulang. Pendiddik juga belum memiliki referensi materi pembelajar untuk meningkatkan kemampuan. bahasa inggris anak usia dini. Oleh peneliti terarij serta hendak melaksanakan riset, atau penenelitia. dengan judul "pengembangan media buku kegiatan tema semester 1 untuk meningkatkan kemampuan bahasa inggris AUD".

\section{Metode Penelitian}

Pada penelitian ini saya mengunakan jenis penelitian riset dalam rangka $\mathrm{R} \& \mathrm{D}$ atau sering dikenal dengan Reseach and development. Sukamdinata mengutip suport yang mengatakan bahwa penelitian dan pengembangan adalah suatu pendekan penelitian dalam pengembangan barang baru dan penyempurnaan yang sudah ada.

Penelitian dan pengembangan tidak hanya merupakan produk hang benar-benar baru, akan tetapi juga dapat didasarkan pada penelitian, penelitian dan pengembangan ini dan kemudian dapat dikembangkan dan dievaluasi untuk menghasilkan keuntungan dari pada sebelumnya. Dalam riset ini jangkauan pengembangan produk berbentuk buku kegiatan untuk menstimulasi kemampuan bahasa inggris AUD. Produk yang dikembangkan berupa buku kegiatan.

Tahapan penelitian dan pengembangan ini berkaitan dengan langkah-langkah richey and Klein berpendapat bahwa "fokus dari perencanaan dan penelitian, pengembangan bersifat analisis daru wal hingga akhir meliputi perencanaan, produksi dan evakuasi. Fokus perencanaan dan penelitian. pengembangan bersifat analisis dan awal hingga meliputi perancangan, produksi dan evaluasi.

Berdasarkan sudut pandang diatas, adapun langkah-langkah yanv saya ambil dalam riset ini adalah penelitian rechey and Klein di level 1.

Untuk mengetahui media yang dikembangkan efektif atau tidak peneliti melakukna validasi. Validasi dilakukan sebanyal tiga kali untuk masing-masing hali. untuk mengetahui layak atau tidaknya buku yang dikembangkan peneliti untuk digunakan. Setelah melakukan validasi oleh masing-masing ahli dan telah memenuhi standar validasi. lalu karya yang dikembangkan di uji cobakan dalam skala kecil. Tempat uji coba ini dilaksanakan di Ra Asshafah Kota Bengkulu dilaksanakan pada 13 maret s/d 27 april.

Informasi merupakan memeroi atas berkas kenyataan. Informasi langkah berkas data mengenai suatu kondisi ataupun permasalahan. Pada penelitian ini mengunakan dua tipe informasi atau jenis data ialah $\mathrm{H}$ 
1. Temuan analisis atau data kualitatif, temuan analisis dengan beberapa ahli ahli pakar materi, pakar bahasa serta pakar desain cove. data atau saran yang telah diberikan oleh pakar atau ahli, sebagai berikut :
a. Saran dan hasil dari instrumen para ahli desai cover, materi dan bahasa
b. Betul menurut para ahli
c. Masuk akal menurut peneliti
d. Pas dan sesuai dengan kebutuhan pertumbuhan dan perkembangan anak

2. Data kuantitatif adalah data yang dikumpulkan melalui kuesioner evaluasi kegiatan buku, untuk meningkatkan kemampuan bahasa inggris anak usia dini yang kemudian dapat di evaluasi secara deskriptif dengan rumus sebagai berikut :

$$
P=\frac{F}{N} X 100 \%
$$

Keterangan :

$\mathrm{P}=$ persentase tingkat perubahan

$\mathrm{F}=$ frekuensi nilai yang diperoleh

$\mathrm{N}=$ jumlah soal

Dalam penelitian ini instrumen pengumpulan data menggunakan angket, wawancara dan dokumentasi.

\section{Hasil Penelitian dan Pembahasan}

Dalam proses pembuatan media buku kegiatan ini, berdasarkan tema yang di angkat yaitu diriku, lingkungan ku, kebutuhanku, binatang da tanaman. Berdasarkan tahap perkembangan padabab sebelumnya, ini adalah ketujuh tahap :

\section{Potensi masalah}

Langkah awal buat menganalisis serta mengenali masalah atau pun penyimpangan. Dalam penelitian ini masalah yang ditemukan kurang menariknya media buku kegiatan anak untuk menstimulasi kemampuan bahasa inggris pada anak usia dini.
2. Pengumpulan informasi

Setelah mengidentifikas kemungkinan masalah, tahap selanjutnya adalah mengumoukan informasi tentang kebutuhan atau mengevaluasi produk untuk dikembangkan dengan menyebarkan kuesioner. Data hasil penyebaran kuesioner selanjutnya akan diolah dan di analisis untuk menjadi produk pengembangan.

3. Desain produk

Produk yang akan dikembangkan berupa materi buku kegiatan yang mencangkup tema pada semester awal yakni dengan tema diriku, lingkungan $\mathrm{ku}$, kebutuhanku, binatang dan tanaman. Pada langkah ini aktivitas yang hendak di coba buat mendesain produk adalah sebagai berikut :

a. Menetapkan produk yang akan dikembangkan yaitu media buku kegiatan untuk menstimulasi bahasa inggris AUD.

b. Menganalisis dan mencari sumber. Pada tahap ini peneliti melakukan analisis terhadap sumber-sumber didapat mencangkup rujukan atau referensi jurnal dan buku buku yang telah ada dan kemudian dikembangkan.

c. Mengembangkan media buku kegiatan setelah mengetahui layak atau tidaknya isi media buku kegiatan maka langkah selanjutnya adalah peneliti melakukan pengembangan media buku kegiatan. adapun antara lain :

1) Judul buku : (English For Kids 1) Pemilihan judul ni didasari pada isi buku yakni mengagkay tema pembelajaran semester

2) Format dan ukuran buku berdimensi A4 $(21$ x 29.7 centimeter) serta mempunyai halaman sebanyak 95 
halamam belum tercantum bungkus depan dean bungkus belakang serta pengantar dan catatan isi.

3) Isi dan unsur-unsur buku english for kids 1 adalah buku aktifitas yang dibuat dengan imajinasi, minat dan nilai esai pertumbuhan anak. Buku ini memiliki sampul, kata pengantar, tabel isi dan subjek penulis. Gambar dan warna warna yang dikenakan dalam buku ini diadaptasi berdasarkan analisis kebutuhan yang penuh warna, menarik, dan sederhana yang cocok untuk anak usia dini.

4) Komponen-komponen yang dikembangkan atas dasar pertimbangan dan kemampuan bahasa inggris anak usia dini, yaitu:

a) Topik produk ini adalah mata pelajaran semester 1

b) Kegiatan pembelajaran berdasarkan karakteristik perkembangan anak

c) Mendorong kemampuan bahasa inggris anak usia dini.

5) Desain gambar dan teknik pengerjaannya, Gambar yang dibuat dalam alat dan buku aktivitas ini mengunakan gambar-gambar yang didapat dari searching internet, dari aplikasi freepik serta aplikasi pinteres yang kemudian di satukan dan dikembangkan sehingga membentuk suatu gambar yang kemudian dijadikan bahan untuk belajar. Ada kan teknik pengerjaannya mengunakan microsoft word, corel draw pada komputer.

6) Warna dan tifografi

Warna yang dipakai dalam buku ini merupakan motif jelas serta terang buat menarik simpati anak. Ada pula tofografi yang dimanfaatkan dalam pengembangan alat buku kegiatan ini merupakan Comix Sans Ms dan untuk isi dari materi yang digunakan dan times new roman untuk daftar isi. Tujuan dari tofgrafi ini mencari forn yang menarik dan sesuai untuk anak usia dini.

\section{Validasi Desain}

Desain produk yang dibuat oleh peneliti selanjutnya di validasi oleh para ahli, ahli yang pertama ahli materi, ahli bahasa dan ahli desain cover. Berikut merupakan hasil validasi produk dari ketiga ahli :

\section{a. Validas tahap pertama}

Validas awal dilakukan pada tanggal 9, 10 dan 11 april 2021 yang pertama dilakukan oleh bunda erni selaku ahli materi, kemudian dilanjutkan dengan ahli bahasa kemudian dengan ahli desain cover.

Berdasarkan data validasi ini, evakuasi dan komentar bunda erni pada buku english for kids 1 ini yakni masih banyak kalimat perintah yang belum dimengerti anak. Pada tabel dibawah ini menunukan hasil persentase yan dilakukan pada saat validasi pertama oleh ketiga ahli.

Tabel 1. Hasil validasi pertama

\begin{tabular}{|lll|}
\hline Validator & Hasil persentas \\
\hline Ahli materi & B & $60 \%$ \\
\hline Ahli bahasa & B & $60 \%$ \\
\hline Ahli desai cover & B & $80 \%$ \\
\hline Rata-rata & & $66 \%$ \\
\hline
\end{tabular}


Berdasarkan tabel di atas, dapat diketahui bahwa produk media buku kegiatan mendapatkan nilai yang baik dari ketiga validator atau ahli dengan skor persentase $66 \%$, sehingga dengan adanya hasil validasi pertama dari beberapa pakar atau ahli tersebut, maka media buku kegiatan yang dikembangkan perlu adanya perbaikan sesuai masukan dari ketiga ahli. Dan produk yang dikembangkan belum menenuhi kreteria perkembangan bahasa inggris AUD sehingga belum kayak digunakan.

\section{b. Validasi tahap kedua}

Validasi kedua dilakukan pada tanggal 12, 13 dan 14 april 2021. Pada tabel kedua menyatakan hasil persentase yang diberikan pada saat validasi kedua oleh ketiga ahli. Adapun hasilnya validasi kedua ialah sebagai berikut :

Tabel 2. Hasil validasi kedua

\begin{tabular}{|lcc|}
\hline Validator & Hasil & Persentas \\
\hline Ahli materi & SB & $90 \%$ \\
\hline Ahli bahasa & B & $70 \%$ \\
\hline Ahli desai cover & SBk & $80 \%$ \\
\hline Rata-rata & & $80 \%$ \\
\hline
\end{tabular}

$$
\begin{aligned}
& \text { Pada validasi tahap kedua ini } \\
& \text { produk yang dikembangkan } \\
& \text { mendapatkan nilai yang sangat baik } \\
& \text { dengan presntase rata-rata } 80 \% \text {. }
\end{aligned}
$$

\section{c. Validasi tahap ketita}

Pada validasi ke 3 yang dilakukan pada tanggal 15. 16 dan 17 april 2021 menunjukan hasil persentase yang dilakukan pada saat validasi ketiga kalinya dari ketiga ahli.

\section{Tabel 3. Hasil validasi ketiga}

\begin{tabular}{|lc|}
\hline Validator & Hasil persentas \\
\hline Ahli materi & SB $100 \%$ \\
\hline Ahli bahasa & SB $80 \%$ \\
\hline Ahli desai cover & SB $100 \%$ \\
\hline Rata-rata & $93 \%$ \\
\hline
\end{tabular}

Keterangan Tabel

B : Baik

SB : Sangat baik

Pada tahap validasi ketiga atau yang terakhir yang dilakukan oleh kegita ahli atau pakar mendapatkan persentase nilai rata-rata $93 \%$ persen. Dengan melauli beberapa tahap validasi yang dilakukan sehingga peneliti mendapatkan hasil yang maksimal dari beberapa ahli atau pakar yang memiliki penilain yang berbeda-beda dengan hasil yang sangat baik, maka dari itu media buku kegiatan untuk menstimulasi kemampuan bahasa inggris ina layak untuk diuji cobakan dengan perbaiakn dan saran dalam pemebelajaran bahasa inggris AUD.

\section{Perbaikan produk}

beberapa usulan dan komentar untuk penambahan atau pengurangan desai produk diperolah berdasarkan hasil validasi yanh dilakukan. Beberapa modifikasi produk sebelum dan sesudah validasi disediakan.

Gambar 1. Perbaikan sampul buku

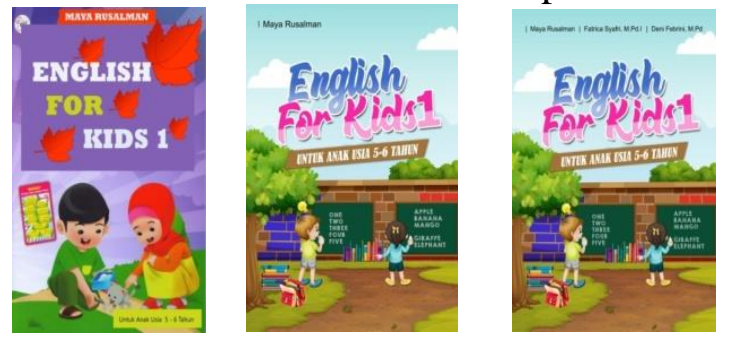

Pada cover sangat banyak mengalami perubahan. Font pada judul buku mengalami perbaikan. Menurut ahli desain cover forn yang sebelumnya kurang menarik. Bukan hanya font saja yang mengalami perubahan tapi gambar atau background juga mengalami perubahan. Karena gambar backgroundnya mengalami perubahan warnanya berubah atau disesuaikan dengan gambar. Pada validasi desain kedua sampul depan sudah ditambah 
nama pembimbing dan nama pembuat di atasnya. Perubahan isi buku dan grafika, isi buku dalam penelitian ini telah melangalami banyak modifikasi baik dalam cara penulisan, gambar makin bahasa yang digunakan. Jenis forn dan kecik bersae pada forn berbeda dalam sistem penulisan hang diubah. Tujuannya adalah untuk menjadi menarik dan komprensensif. Anatomi buku meliputi tema pada isi buku.

6. Uji coba skala kecil

Produk yang telah diberi penilaian dan diperbaiki oleh pakar dan ahli kemudian diujicobakan di RA AsShaffah kota bengkulu dengan jumlah 14 anak, produk-produk yang telah diracik oleh para profesional dan ahli lalu ditelaah. Tujuan dari penelitian ini adalah untuk mengetahui bagaimana produk yang dikembangkan ini mempengaruhi perkembangan bahasa anak usia dini, khusunya keterampilan bahasa inggris AUDi. Pengujian ini berlangsung pasa 26-3 mei 2021.

Adapula hasil riset yang sudah diuji cobakan pada 14 anak di RA AsShaffah kota bengkulu.

Tabel 4.10 Hasil Pengisian Lembar Observasi

\begin{tabular}{|l|l|l|}
\hline No & Nama & Katagori \\
\hline 1 & Ghassan & BSH \\
\hline 2 & Abiyan & MB \\
\hline 3 & Raffa & MB \\
\hline 4 & Afiqah & BSH \\
\hline 5 & Azra & BSH \\
\hline 6 & Filzah & BSH \\
\hline 7 & Naufal & bSH \\
\hline 8 & Daffah & BSH \\
\hline 9 & Kenzio & BSH \\
& Darunaahsiy & \\
\hline 10 & Agam & BSH \\
\hline 11 & Bilqis & BSH \\
\hline 12 & Nabilah & BSH \\
\hline 13 & Abam & MB \\
\hline 14 & Irjie & MB \\
\hline
\end{tabular}

Sumber. Hasil pengisian observasi

\section{Proses Pembuatan Produk}

Cara pembuatan produk alat buku aktivitas debganbtema diriku, lingkunganku, kebutuhanku, binatang dan tanaman buat memotivasi keahlian bahasa inggris AUD diawali dengan metode mencari sumber-sumber buku aktivitas spesialnya untuk menstimulasi kemampuan bahasa inggris AUD. Namun belum ditemukan. media buku kegiatan yang dalam satu buku mencangkup lima tema atau pada pembelajaran semester 1 . Melainkan hanya media buku kegiatan tang disetiap bukunya haya mencangkup satu tema dan seluruh isinyapub tidak semunya berbahasa inggris melainkan mencangkup enak aspek perkembangan anak. Media buku kegiatan yang asli sudah ditemukan oleh peneliti kemudian di analisis. Melihat buku kegaiatn yang sebenarnya ternyata dalam pembelajaran bahasa inggrisnya masih kurang.

Peneliti kemudian menghasilkan produk dengan fokus pada materi subjek saya, lingkungan say, kebutuhan saya, binatang dan tanaman. Peneliti menciptakan ide dan imajinasi mereka sendiri dk dalam struktur buku. Para peneliti kemudian mengumpulkan foto dan membuat frase perintah dari internet setelah media buku ketauan atau aktivitas dikembangkan. Setelah mengumpulkan foto-foto tersebut peneliti membuat sebuah buku termasuk gambar, jenis forns, ukuran kata dan warna yang dipilih untuk produk tersebut. Metode perancangan ini mengunakan program komputer Microsoft word.

Setelah produk selesai kemudian di validasi dengan ke 3 ahli. Ketiga ahli tersebut memberikan usulan dan pendapat dari barang yang di kembang oleh peneliti. Tujuan dari validasi ini adalah untuk menilai tingkat kepraktisan produk untuk kemudian di uji coba kan dalam bentuk skala kecik di RA As-Shaffah. Adapun tanggapan siswa pada saat melakukan uji coba skala kecil ketika mereka melihat hasilnya, reaksi anak-anak sangat senang 
dan sepertinya tidak sabar untuk melihatnya. Bahkan mereka saling berebutan.

\section{Simpulan dan Saran}

Bersumber pada pemaparan pada bab sebelumnya, sehingga dapat dismpulka bahwa :

1. Menurut penilaian para ahli media buku kegiatan tema diriku, lingkunganmu, kebutuhanku, binatang dan tanaman untuk menstimulasi kemampuan bahasa inggris AUD sudah layak digunakan dan telah di validasi serta dinujicobakan

2. berdasarkan hasiln yang dilakukan pada percobaan skala kecil di Ra AsShaffah kota bengkulu alat buku kegiatan ini bisa digunakan untuk meningkatkan kekamouan bajasa inggtis AUD dalam katagori berkembang sesuai harapan.

\section{DAFTAR PUSTAKA}

Adam Steffi Dkk. 2015. "Pemanfaatan Media Pembelajaran Berbasis Teknologi Infoemasi Bagi Siswa Kelas X SMA Ananda Batam

Arumsari. Adini Dwi Dkk. 2017. "Pembelajaran Bahasa Inggris Pada Anak Usia Dini Di Kec Sukokilo Surabaya”, Jurnal Pg-PAUD Trunojoyo

Djamarah, Syaifu Bahri. 2011. Psikologi Belajar. Jakatra : PT Reinika Cipta.

Dinda Chaira. 2017. Skripsi mengenbangkan Bahasa Anak Usia Dini Melalui Media Audio Visual Di Taman Kanak-Kanak Asalam Bandar Lampung, Universitas Islam Negeri Raden Intan Lampung
Dhieni Nurbiana. 2013. Metode Pengembangan Bahasa, Banten : Universitas Terbuka

Fatmawati, Suci Rani. 2015. Pemerolehan Bahasa Pertama Anak Menurut Tinjauan Psikolinguistik, Jurnal Lentera

Fakultas Tarbiyah Dan Tadrisninstitut Agama Islam Negeri Bengkulu, Pedoman Penulisan Skripsi, (Bengkulu : FTT IAIN BENGKULU)

Guslinda, Rita Kurna. 2018. Media Pembelajaran Anak Usia Dini. Surabaya : Jakad Publishing.

Harsela, febey, didik suryadi. 2012. Analisis kemampuan guru paud dalam pembuatan media pembelajaran dikecamatan jarai kabupaten lahat simatera selatan. Vol.4 no.2. universitas bengkulu. Jurnal alfitrah

Hj Asiyah Dkk. 2017. Pengembanagnmateru Ajar Audio Visual. Bengkulu : Vanda

Hamzah Amir. 2019. Metode Penelitian Dan Pengembangan Research And Development, Malang ; Literasi Nusantara

Khairani, Ade Irma. Pendidikan Bahasa Inggris Untuk Anak Usai Dini, jurnal Politeknik Negeri Medan.

Khadijah. 2015. Media Pembelajaran Anak Usia Dini. Medan : Perdana Publish.

Miftah M, 2013. "Fungsi Dan Peran Media Pembelajaran Sebagai Upaya Peningkatan Kemampuan Belajar Siswa”, Jurnal Kwangsa 
Musbikin, Imam. 2010. Buku Pintar PUAD. Yogyakarta : Laksana.

Nurlela Lela. 2018. Skripsi Pengembangan Media Pembelajaran Busy Book Dalam Meningkatkan Kemampuan Bahasa Anak Usia Dini Di Play Group Islam Bina Balita Way Halim Bandar Lampung Tahun Ajaran 2017/1018

Otto Beverly. 2015. Perkembangan Bahasa Anak Usia Dini, Jakarta : Prenadamedia Grup

Purwati Agus. 2018. Pengembangan Buku Bergambar Sebagai Media gpemerolehan Bahasa Indonesia Anak Paud

Robingantin, ulfha Zakiyah. 2019. Pengembangan Bahasa Anak Usia Dini. Yogyakarta : Ar-Ruzz Media

Rahayu Sri. 2017. Pengembangan Bahasa Pada Anak Usia Dini.Yogyakarta : Kalimedia

Sa'adah Risa Nur, Wahyu. 20120. Metode Penelitian R\&D (Reseach And Development). Malang : Literasi Nusantara

Siregagar Rahmah Ferdiani. 2017. Penerapan Buku Cerita Bergambar (Ig Book) Dalam Perkembangan Bahasa Anak Usia Dini Kelompok B Di Ra Nurul Iman Kecamatan Pantai Cermin Kabupaten Serdang Bedagai T.P 2017/2018

Sugiyono. 2015. Metode Penelitian Kuantitatif, Kualitatif Dan $R \& D$ Bandung : ALFABETA.

Sugiyono. 2016. Metode Penelitian Kuantitatif, Kualitatif Dan $R \& D$. Bandung : ALFABETA
Susanto Ahmad. 2017. Pendidikan Anak Usia Dini. Jakarta ; Bumi Aksara

Susanto Ahmad. 2011. Perkembangan Anak Usia Dini Pengantar Dalam Berbagai Aspknya. Jakarta : Kencana

Suyadi, ulfha Maulidya. 2013. Konsep Dasar PAUD. Bandung : PT Rosdayakrya.

Suyadi, 2004. Teori Pembelajaran Anak Usia Dini Dalam Kajian Neurosaind. Bandung : PT Remaja Rosdakarya.

Umam Muhammad Choerul. 2017. Pengembangan Media Pembelajaran Bahasa Inggris Pada Pendidikan Anak Usia Dini Berbasis Android Package Di Paud Permata Bunda Bawen 2016

Usman, Muhammad. 2015. Perkembangan bahasa dalam bermain dan permainan. Yogyakarta : CV budi utama.

Upton Penney. 2012. Psikologi Perkembangan. Jakarta : Erlangga

Wiyani, Novan Ardy. 2016. Konsep Dasar PAUD. Yogyakarta : Gava Media.

Yus, Anita. 2011. Model pendidikan anak usia dini. Jakarta : kencana.

Yusuf Syamsu, Nani M.Sugandhi. 2012. Perkembangan Peserta Didik. Bandung : PT Raja Grafindo Persada

Zaman Banru, Cucu Eliyawati. 2010. Bahan Ajar Pendidikan Profesi Giri (PGG), (Skripsi Pendidikan Guru Pendidikan Anak Usia Dini (PAUD), Fakultas Pendidikan, Universitas Pendidikan Indonesi 